\title{
FORMATION OF GLOBAL INFRASTRUCTURE IN THE CONTEXT OF SOCIAL, ECONOMIC AND ENVIRONMENTAL INTENTIONS
}

\author{
Danyila Olijnyk $^{1}$, Yurii Konizhai ${ }^{2}$ \\ ${ }^{I}$ Doctor of Economics, Professor, Senior Researcher, National Institute for Strategic Studies, Kyiv, Ukraine, \\ e-mail: olijnukd@i.ua,ORCID: https://orcid.org/0000-0001-8144-6482 \\ ${ }^{2}$ Student at Salzburg University of Applied Sciences, ORCID: https://orcid.org/0000-0001-7854-2561
}

The dynamic changes that are currently taking place in countries based on longterm structural change are unprecedented and driven by a new geopolitics. That underpins the biggest global challenges facing the world today. The actual effectiveness of positioning the global presence of states according to the Elcano Global Presence Index is currently evaluated in three dimensions: economic (energy, raw materials, production, services and investment), military (number of servicemen on international missions and bases abroad) and "soft" (migration, science, technology, database, Internet bandwidth, technology focused on patents, education, information, tourism, sports, culture and humanitarian assistance). Ukraine ranked 52 nd out of 70 countries in the global presence rating in 2017 [1].

The global presence of developed countries now aims to dominate the global infrastructure of the future on a strategic basis. For example, China implements the vision of the future in the "Made in China 2025" strategy[2] and "Beijing Wants A.I. to Be Made in China by 2030" [3]. In India, the strategy is to achieve the potential of digitizing production by 2030 [4]. South Korea plans to implement global hydrogen technology standards by 2030 [5]. In the US, strategic intentions for 2030 are dominated by production and military goals [6]. In the face of growing threats to electricity-based infrastructure, the US Department of Energy is launching a North American model of energy resilience to enhance multi-sectoral infrastructure and national security (North American Energy Resilience Model, NAERM) [7].

In this paper, we will focus only on the economic component, since the use of energy resources, services and investments now requires dramatic changes in the approaches of all market participants.

Ukraine has taken a course towards the completion of an integrated energy market with Europe and the development of a national energy strategy with low levels of greenhouse gas emissions for sustainable development aimed at improving economic efficiency, energy security and the environment (Energy Security, Economic Efficiency, and Environment + Safety, " $3 E+S$ ") and needs urgent decisions on access to clean energy and national energy and climate plans (National Energy and Climate Plans, NECPS).

The crucial role in integrating countries into the single energy market, which affects the survival of the planet, is played by timely and managed energy transition 
and synergies between energy security, access, accessibility and environmental sustainability. The existing energy infrastructure has been built over the last decades on the basis of the use of coal, oil, natural gas and nuclear energy. At present, there is a departure from the basic values of security, reliability, on which existing energy systems were built, and a new paradigm of values of sustainability, flexibility and accessibility is being formed, which is provided with a completely new way of energy production, supply and consumption. Ukraine holds "umbrella" patents on a new way of organizing and operating the grid, which is regulated in strategic and regulatory documents as early as 2006 [8].

In a hydrocarbon-based commodity economy, the decarbonisation of domestic sectors of industry, energy, heat, gas production and transportation, as a rule, was carried out as separate processes. Achieving zero $\mathrm{CO}_{2}$ emissions requires crosssectoral integration, enabling the energy sector to supply them with clean energy, without which the transition to a carbon-free activity model is impossible. There are "carbon-free" $\left(\mathrm{CO}_{2}\right.$-free) and "carbon-neutral" hydrogen. The first type is "green" hydrogen, made from water by the method of electrolysis based on RES. The second type is "blue" hydrogen produced from natural gas using carbon capture and storage (CCS) technologies

Emphasis is placed on both the global transition to clean energy, energy security and the direction of the energy sector towards meeting international climate targets for reducing carbon emissions, focusing on all fuels and existing technologies to achieve this goal.

For reference. According to Carbon Tracker research, the world's fossil fuels for energy and mining companies account for 2,795 gigatons of $\mathrm{CO} 2$, which is incompatible with meeting the goals of maintaining a global average temperature rise of 2050 below $2^{\circ} \mathrm{C}$. In these circumstances, the urgent task is to prepare the real economy and financial markets for the risks associated with climate and energy transitions and to generate the new way of thinking [9].

The Pan-European Strategic Framework for Greening the Economy [10] and the Green Economy Initiative [11] foresees that the development of the pan-European countries is aimed at ensuring the sustainable use of ecosystems and natural resources to meet the needs of present and future generations. The strategic framework builds on the political effort to implement the results of the Rio +20 Conference and the 2030 Agenda for Sustainable Development. The main theme of the UN General Assembly for 2020 on Sustainable Development is defined as "Forced action and ways of transformation: implementing a decade of action and accomplishment for sustainable development"[12].

Future scenarios are based on the development of a sustainable energy model. The energy system, as a whole, will have to develop in the most optimal way in order 
to meet the new tasks and needs of its consumers. Ukraine is one of the most energy consuming countries in the world. The annual loss of the national economy from inefficient use of energy is estimated at 15-17 billion U.S. dollar. The country has the highest energy intensity of GDP in the EU. This is mainly due to the poor condition of the energy infrastructure, high losses in energy conversion, transmission and distribution, low efficiency of fuel and energy resources in technological processes (mainly energy-intensive industries), as well as low efficiency in final consumption sectors.

For reference. According to the National Commission for the State Regulation of Energy and Utilities, energy losses in Ukraine reach 100 million UAH hryvnia daily and water losses are estimated at 4 million UAH hryvnia [13].

The energy system of Ukraine is a unique organizational and technical object, the structure of which is multilevel and formed on the hierarchical principle, which provides balanced unity of generation, network distribution and consumption to allow the inter-system exchange of power and energy flows in normal and emergency conditions. At the same time, Ukraine's power system, created more than 70 years ago, requires both the modernization of fixed assets and the replacement of physically and morally outdated equipment, as well as the use of new technologies and equipment of information-diagnostic systems and control systems.

Defining the conceptual foundations and practical mechanisms for ensuring the sustainability of the energy system is the key to shaping Ukraine's secure and sustainable energy future. However, in terms of ecological footprint per capita in 2019 , Ukraine ranked only $91^{\text {st }}$ place (Belarus $-41^{\text {st }}$ place). In the structure of the fuel balance of the electric power industry of Ukraine, renewable energy sources are in the last place (4.4\%) after oil (14.3\%), nuclear power (25.1\%), gas (27.4\%).Coal ranks first $(28.7 \%)$ (Table 1$)$.

Table 1. Energy balance of European countries for 2017 (thousands of tonnes of oil equivalent)

\begin{tabular}{|l|c|c|c|c|c|c|c|c|}
\hline Country & Total & Coal & $\begin{array}{c}\text { Natural } \\
\text { Gas }\end{array}$ & $\begin{array}{c}\text { Nuclear } \\
\text { Energy }\end{array}$ & $\begin{array}{c}\text { Hydro } \\
\text { Energy }\end{array}$ & $\begin{array}{c}\text { Wind, } \\
\text { sun etc }\end{array}$ & $\begin{array}{c}\text { Biofuels } \\
\text { and waste }\end{array}$ & Oil \\
\hline Europe & 1998105 & 321869 & 504120 & 244092 & 49751 & 67442 & 174284 & 635011 \\
\hline Germany & 311245 & 71414 & 75341 & 19887 & 1733 & 13407 & 31012 & 102965 \\
\hline France & 247086 & 9891 & 38492 & 103796 & 4297 & 3579 & 17912 & 72568 \\
\hline $\begin{array}{l}\text { United } \\
\text { Kingdom }\end{array}$ & 175883 & 9564 & 67839 & 18327 & 510 & 5344 & 12414 & 60616 \\
\hline Turkey & 146797 & 40089 & 44232 & & 5006 & 10170 & 3032 & 44318 \\
\hline Poland & 103845 & 49421 & 15445 & & 220 & 1373 & 8145 & 29028 \\
\hline Ukraine & 89462 & 25757 & 24554 & 22449 & 769 & 149 & 2989 & 12696 \\
\hline
\end{tabular}

Source: IEA World Energy Balances 2019 
Despite the fact that in 2018 the share of renewable energy sources in the energy sector has increased up to $25 \%$ in 2018 , but this result has practically not affected the amount of carbon dioxide emissions. Thus, in 2018, a record increase of $\mathrm{CO}_{2}$ emissions of $1.7 \%$ was recorded. This is due to the fact that more than $40 \%$ of the world's $\mathrm{CO}_{2}$ emissions are from the energy sector, while $60 \%$ is from other sectors, mainly transport and construction, industry and housing. The integration of renewable energy production and consumption sectors is an integral factor and the foundation for the further development of renewable "green" energy through the availability of renewed infrastructure for the transportation, distribution and end use of energy-intensive hydrogen and synthetic (e-Fuel) produced from renewable electricity.

Within the framework of the formation of global infrastructure networks based on the combination of energy, information and communication technologies, it is envisaged to increase significantly the availability of electricity and increase the security of energy supply without increasing the environmental burden. On this basis, since recent years, significant changes have taken place in the world of electric power. First of all, in the field of energy management, which are aimed at energy saving, security, reliability and reduction of the share of hydrocarbon energy, a competitive market for system technological services (frequency and power regulation, load shutdown in case of accidents etc).

A report on the long-term future of energy infrastructure in Germany and the Netherlands states that by 2050 the need for hydrogen imports is estimated at 10.3 million tonnes annually. For countries such as Japan, Germany, South Korea, the Netherlands, Malaysia and Singapore, the estimated supply of hydrogen for the decarbonisation of transport, industry, electricity and housing is 25 million tonnes per year [14]. According to the Julich Research Center, prices for imported hydrogen in Germany will reach 3.9 U.S. dollar per kg [15].

Such a power transition conditionality for merging sectors is currently considering the introduction of Power-to-X technology, which refers to conversion technologies that allow the separation of electricity as a commodity for use in other sectors, using energy provided through additional investment in production.

In fact, energy infrastructure is seen as a vision of a unified system of systems that takes into account the specific features of different objects, processes and phenomena combined into such a system and subject them to the degree laws of natural and social processes. Thus, the transition from centralized production and vertically integrated monopolies to decentralization, digitization, creation of energy clusters, micro-networks characterized by accelerated rates of electrification, formation of digital ecosystems, services focused on data and the emergence of a 
class of energy consumers and simultaneously produce and energy consume energy [16].

A new global approach to power generation, transmission, distribution, measurement, supply, storage and storage, as well as electricity consumption, is needed to achieve these goals. This should set out the clear technological requirements laid down in the standards and other regulations for the interaction of a wide range of sectors (such as automation and operation of the network, management of distributed energy resources, automation of residential and industrial buildings, intellectual accounting), providing for a high level of consistency, reliability, data protection and privacy, as well as profitability.

One of the particular problems to be solved in Ukraine in the near future is the issue of ensuring the unity of measurements of reactive electric power (energy) in the conditions of continuous increase in the number of nonlinear loads (consumers creating extremely large current disturbances) in networks of all levels, including rural networks. and housing and utilities networks. Reactive power is one of the most important determinants of power grid losses. On the other hand, reactive power and associated overloads, voltage fluctuations, symmetry and stability of three-phase power systems are one of the common causes of power system failures. That is why at the annual meeting GO15 strategic directions of formation of decarbonized energy infrastructure for 2020 identified network instability and system inertia [17].

Connecting to a digital infrastructure consisting of various assets, systems, functions and networks, including power grids, is considered to be one of the most important organizational and technical measures that promotes communication with communities, economies and nations through transport, communication, and energy. and water networks by providing access to core services and markets - in trade, logistics, mobility and information.

Infrastructure is an engine of economic growth that can be improved with innovative technologies, which increases the value of infrastructure projects and increases the efficiency in creating, operating and maintaining quality infrastructure to achieve better social, economic and environmental outcomes. This is facilitated by the integration of digital infrastructure data with physical infrastructure data (InfraTech). This combination of physical and digital infrastructure generates assets that can be automated in a real-time in terms of efficiency, productivity and user experience. As a result, new opportunities are emerging to reformat existing infrastructure assets through scalable data collection, real-time asset monitoring and process automation.

A number of important documents have been adopted to support global infrastructure projects under the G20 and to modernize infrastructure through 
technological innovation, increased sustainability, compliance with public policy requirements, and environmental issues:

- Global Infrastructure Connectivity Alliance Initiative (2016) [18],

- African Partneship G20 (2017) [19],

- Roadmap to "Developing Infrastructure as an Asset Class" (2018) [20] and

- G20 High Level Principles on Sustainable Habitat through Regional Planning (2018) [21].

Investments in energy infrastructure are an area of long-term profitability and require large-scale implementation of standardization systems for the integration of energy storage technologies, energy efficiency, asset management, etc. in order to ensure in real time the optimal functioning of a single energy system, one of which is electricity consumers.

The G20 Summit in Hangzhou adopted a declaration emphasizing the importance of investing in infrastructure for cost-effectiveness, security, disaster resilience, job creation, capacity building and knowledge and know-how transfer while mutually agreeing and environmental impacts in accordance with agreed development strategies. A key issue in this context is technological trends and the speed of decision-making based on the formation of intellectual property rights policy (Intellectual Property Rights, IPR).

Particular attention was focused on obtaining data on investments in digital infrastructure and analyzing them as a key factor in decision-making support for the development of important infrastructure energy projects. An existing energy infrastructure is considered to be a valuable asset portfolio that plays a crucial role in the global transition to a low carbon energy environment and can have a huge impact on the global economy. This is facilitated by satellite data on basic energy infrastructure under the European "Green New Deal", which aims to ensure climate neutrality by 2050 and identify sources of greenhouse gas emissions, as one of the key key elements in reducing greenhouse gas emissions in the energy sector [22]. Scientific studies have shown the harmfulness of greenhouse gases such as: carbon dioxide, methane, nitrous oxide, hydrofluorocarbons, perfluorocarbons and sulfur hexafluorides.

Mane discussions are currently underway to establish technical thresholds (taximetry) for the economic feasibility of limiting $\mathrm{CO}_{2}$ emissions for electricity production, which EU experts have previously set at $100 \mathrm{~g} \mathrm{CO}_{2}$ per $\mathrm{kWh}$. This approach will allow investors, retirement funds and private companies to determine what relates to "green" financing and shift financial flows from "carbon" to more sustainable economic activity.

An independent group of scientists led by Jeffrey D. Sachs estimates that greenhouse gas emissions and sustainable development will require 22.6 trillion U.S. dollars over 2016-2030. 
The World Energy Council (WEC) states that the transition to a decarbonized energy system and the formulation of integrated energy-industrial strategies is the basis for managing dynamic sustainability based on the best ways to use existing energy assets to ensure a reliable and sustainable energy transition to a sustainable energy transition [23].

Assessing the economic impact of future investment potential, based on the example of energy infrastructure, is devoted to the report of the Board of Canada Conference on "statistics that can be relied upon" [24]. Recommendations to the report for the development of energy infrastructure suggest investing in activities such as the operation of fixed networks intended to provide services to the public in connection with the production, transportation or distribution of electricity and the supply of electricity to such networks [25].Investment in Canada's energy infrastructure from 2011 to 2030 is estimated at $\$ 347.5$ billion U.S. dollars. Investment in energy infrastructure is projected to generate an additional 10.9 billion U.S. dollars annually in real GDP and create an average of 156,000 jobs.

Attracting investment in global infrastructure projects is seen as a set of Perfomance Granding Index (PGI) databases into quality infrastructure (Quality Infrastructure Investment Database, QII) [26].

According to scientists, the cost of the world's fossil fuel resources can be reduced from 1 to 4 trillion U.S. dollars by 2035 as a result of accumulated assets [27].

In order to create an infrastructure database as an asset class, the Global Infrastructure Investment Database (EDHEC) is now being created at EDHEC (EDHECinfra), covering over 500 infrastructure assets in 10 different countries over the last 20 years [28]. The assets of companies are focused on environmental, social and management indicators (Environmental, Social, and Governance, ESG) and are determined by a weighted global Securities Capitalization Index (MSCI), listed on the stock exchange and included in the infrastructure of the Global Industry Classification System (Global Industry Classification System, GICS) [29]. MSCI, thus, it provides a more detailed understanding of the performance of global infrastructure and the sectors that are connected to it.

The measurement of the performance of large and medium-sized segments of the market in Ukraine is carried out using the MSCI index for 6 groups of factors that have historically demonstrated excess long-term market profitability and cover approximately $85 \%$ of equity in Ukraine [30].

The development of domestic capital markets is essential to support the growth and enhancement of financial stability in local currency bond markets. Of particular importance is the mobilization of sustainable financing and financial integration in 
connection with the transition of markets by the end of 2021 from LIBOR to alternative reference rates.

Blockchain, in conjunction with Internet of Things (IoT), is considered internationally as an innovative mechanism for green financing of energy infrastructure in order to reduce transaction costs, increase transparency and availability of reliable data for so-called tokenized securities (digital asset representation) (Sanderson 2018; Merrill, Schillebeeckx \& Blakstad 2019). For Ukraine with high budget deficits, quantitative easing (QE) of debt-to-GDP monetization can be used to stimulate the growth of the national economy. There are three categories of tokenized securities: (a) asset-based tokens that represent the ownership of an asset as real estate, commodities or works of art; (b) debt tokens representing debt instruments, such as green bonds or real estate collateral; and (c) equity tokens that reflect the value of the shares issued by the companies and entitle the investor to the company's profits and voting rights as shares. However, as noted by the Asian Development Bank (ADB), immature investment infrastructure and regulatory uncertainty are currently limiting the implementation of blockchain-based tokenized securities [31].

International institutions are encouraged to promote the integration of countries and regions into global infrastructure, such as the :

- European Africa African Infrastructure Trust Fund (EU-AITF) [32],

- Africa-EU Energy Partnership (AEEP) [33],

- China's Massive Belt and Road Initiative [34],

- Initiative for the Integration of Regional Infrastructure in South America [35],

- Regional Integration and Economic Development In South Asia [36] etc.

In addition, a Global Infrastructure Hub (GI Hub) has been established to promote enhanced access to global infrastructure, working with governments around the world and multilateral financial institutions to coordinate the quality of infrastructure projects throughout their lifecycle. Already 130 banks have adopted business strategies that align with the United Nations Sustainable Development Goals (SDGs) and impact on global infrastructure. This approach makes it possible to create conditions that will contribute to infrastructure investment and reduce environmental impact. According to the GRI Glossary, infrastructure is interpreted as facilities primarily designed for the provision of public services or goods, from which organizations do not seek direct economic benefits (roads, schools, hospitals, water supply).

Although infrastructure is crucial for sustainable development, in terms of investment needs of the market, both developed and developing countries are experiencing a lack of adequate financing, which is hampering development in social, economic and environmental terms. It is worth noting that in 2017 , institutional 
investors' private savings reached 80 trillion U.S. dollars in managed assets [37], while 90 percent of institutional investors intend to increase their assets in the infrastructure sector [38].

As of January 25, 2019, the external debt of Ukraine amounted to 78323 million U.S. dollars and it is $63 \%$ of GDP [39]. Governments raise debt capital to stimulate economic growth.

The Eastern Partnership (EaP) Joint Political Initiative, as a platform for cooperation between the EU and Ukraine, aims to deepen and strengthen relations between European Union and post-Soviet countries (Armenia, Azerbaijan, Belarus, Georgia, Moldova).

Within the framework of the EaP GREEN program on greening the economy in the EU's Eastern Partnership countries, the Ukrainian government creates an integrated policy framework for the transition to a green economy by: reforming policy instruments, adopting new analytical instruments, improving access to finance, supporting capacity development and piloting into infrastructure [40].

The 20 Priorities for 2020 are the priorities to support development that balances and integrates economic, social and environmental dimensions of sustainability.

The Hamburg Climate and Energy Action Plan for Growth underlines the importance of the framework to encourage the necessary additional investment in technological innovation in energy efficiency as an engine of economic growth and recognizes the G20's energy efficiency [41]. Investment Toolkit - A set of voluntary options for participating countries to increase energy efficiency in the G20 economies as an integrated approach to enhancing capital flows towards energy efficiency.

The structural changes that are taking place in the Ukrainian economy necessitate the resolution of fundamental structural problems that have arisen as a result of the financial and economic crisis and the need to mobilize resources for the modernization of transport, municipal and energy infrastructure.

An important role in the economic development of Ukraine is played by the implementation of joint projects with international financial institutions (IFIs). In 2019, the Cabinet of Ministers of Ukraine adopted the Concept of Improving the Effectiveness of Implementation of Joint Projects with the IFIs [42], which provides for a change in approaches to the selection of project compliance with the existing priorities of Ukraine, including:

- development of instruments for minimizing currency risks,

- creating a platform for information exchange and a multi-level project monitoring system,

- regular reviews of the loan portfolio and

- creating an open register of IFI projects. 
Although the issue of Ukraine's co-operation with IFIs is a matter of ongoing consideration, a comprehensive analysis of project implementation and the level of sampling of IFI projects in Ukraine is uneven. Thus, in 2019, the sample rate of funds for the World Bank Group (International Bank for Reconstruction and Development, International Development Association, International Finance Corporation, Multilateral Investment Guarantee Agency, International Center for Investment Disputes Settlement) is only 27.02\%, European Bank for Reconstruction and Development - 48,22\%, European Investment Bank - 15,6\% and German State Development Bank (KfW) - 4,9\%. In general, problems arise at every stage of project preparation and implementation and require a systematic solution. An example of an unfavorable situation in 2018 is the implementation of energy infrastructure projects according to the loans granted under the state guarantees from IFIs:

- project of the International Bank for Reconstruction and Development "Improving energy efficiency in the district heating sector of Ukraine" - 272 million U.S. dollars, since 2014 - sampling of $9.15 \%$;

- European Investment Bank project "Municipal Infrastructure Development Program of Ukraine" - 400 million Euros, since 2015 - 1.8\% sample;

- project of the International Bank for Reconstruction and Development "Transmission of Electricity-2" with the assistance of the Clean Technologies Fund loan amount of 48.5 million U.S. dollars, since 2014 - sample 0.

In addition, Ukraine has selected 200 million Euros of the Eastern European Partnership for Energy Efficiency and Environment (E5R) grant (district heating, solid waste disposal, street consecration, local transport and thermal insulation of public buildings) created for incentives. which should result in a significant reduction in electricity consumption, a reduction of carbon dioxide $(\mathrm{CO} 2)$ and other greenhouse gases over 10 years is only $12 \%$.

A significant challenge for the implementation and financing of IFIs in Ukraine is the complexity of assessing the real impact of international donor programs and projects on socio-economic transformation. This is due to the fact that the measures envisaged by the Framework Program of Partnership of the Government of Ukraine, the International Bank for Reconstruction and Development, the International Finance Corporation, the Multilateral Investment Guarantee Agency for the period 2017-2021, including:

- developing a national infrastructure strategy;

- evaluation and selection of priority innovation projects;

- creation of a single Internet database of investment projects;

- engagement planning, effective use and investment monitoring [42].

Managing such a complex adaptive system on the path to sustainable development requires the implementation of a state policy for managing and 
coordinating interaction in innovative networks, adapting to new knowledge through immanent uncertainty, which generates positive feedback effects.

\section{References:}

1. Elcano global presence 2018 URL:

https://www.globalpresence.realinstitutoelcano.org/en/data/Global_Presence_2018.pdf

2. China to invest big in 'Made in China 2025' strategy URL: http://english.www.gov.cn/state_council/ministries/2017/10/12/content_281475904600274

3. Beijing Wants A.I. to Be Made in China by 2030 URL: https://www.nytimes.com/2017/07/20/business/china-artificial-intelligence.html

4. Digital Manufacturing: Defining India's Vision 2030 URL: http://techcongress.net/blog-digital-manufacturingdefining-indias-vision-2030/

5. Korea to globally standardize 15 hydrogen technologies by 2030 URL: http://www.koreaherald.com/view.php?ud=20190403000439

6. DSIAC's Air Force Science \& Technology 2030 Initiative URL: https://dodiac.dtic.mil/2019/04/18/dsiacsair-force-science-technology-2030-initiative/

7. DOE begins development of North American 'energy resilience model' URL: https://www.utilitydive.com/news/doe-begins-development-of-north-american-energy-resiliencemodel/559902/

8. Pro skhvalennia Enerhetychnoi stratehii Ukrainy na period do 2030 roku URL: https://zakon.rada.gov.ua/laws/show/145-2006-\%D1\%80

9. IPR Policy URL: https://globalplatform.org/wp-content/uploads/2018/03/IPRPolicy-1.pdf

10. The Pan-European Strategic Framework for Greening the Economy. URL: http://www.unece.org/environmental-policy/environment-for-europe/initiatives/greening-the-economy-inthe-pan-european-region/the-pan-european-strategic-framework-for-greening-the-economy.html

11. Batumi Initiative on Green Economy (BIG-E). URL: http://www.unece.org/environmentalpolicy/environment-for-europe/initiatives/big-e.html

12. Ramkova programa partnerstva mizh uriadom Ukrainy ta organizatsiieiu obiednanykh natsii na 20182022 roky.

URL:

http://www.un.org.ua/images/UKR_Ukraine_UN_Partnership_Framework_2018_2020_signed.pdf

13. Zakhody z enerhozberezhennia u sferi elektropostachannia. URL: https://www.nerc.gov.ua/?id=19531

14. Gasunie and TenneT: Climate goals can only be achieved with an integrated European energy system. URL: https://www.tennet.eu/news/detail/gasunie-and-tennet-climate-goals-can-only-be-achieved-with-an-

integrated-european-energy-system/

15. Kosteneffiziente und klimagerechte Transformationsstrategien für das deutsche Energiesystem bis zum Jahr 2050. URL: https://www.fz-juelich.de/iek/iek-3/DE/News/TransformationStrategies2050/_node.html

16. World Energy Scenarios 2016. URL: https://www.worldenergy.org/assets/downloads/World-EnergyScenarios-2016_Summary-Report.pdf

17. GO15 Annual Meeting 2019 hosted by SO UPS - October 2-3, 2019. URL: http://www.go15.org/go15annual-meeting-2019/

18. Global Infrastructure Connectivity Alliance Initiative. URL: http://www.g20.utoronto.ca/2016/globalinfrastructure-connectivity-alliance.pdf

19. Annex to G20 Leaders Declaration G20 Africa Partnership URL: http://www.g20.utoronto.ca/2017/2017-g20-annex-partnership-africa-en.pdf

20. ROADMAP TO INFRASTRUCTURE AS AN ASSET CLASS. URL: https://www.oecd.org/g20/roadmap_to_infrastructure_as_an_asset_class_argentina_presidency_1_0.pdf

21. G20 High Level Principles on Sustainable Habitat through Regional Planning. URL: http://www.g20.utoronto.ca/2018/g20_high_level_principles_on_sustainable_habitat.pdf

22. Professional Forecasts, Available for Everyonee. URL: https://www.predictwind.com/why-predictwindforecast/?gclid=EAIaIQobChMIyr77tOyb5gIVQZSyCh33wgkzEAAYASAAEgIp0fD_BwEryone

23. ENERGY INFRASTRUCTURE Affordability Enabler or Decarbonisation Constraint? URL: https://www.worldenergy.org/assets/downloads/Innovation-Insights-Brief-Energy-Infrastructure-

Affordability-Enabler-or-Decarbonisation-Constraint.pdf

24. Shedding Light on the Economic Impact of Investing in Electricity Infrastructure Economic Performance and Trends. URL: https://www.conferenceboard.ca/temp/d7b4ae9f-7a3c-4f7c-af32-8e282a4cb336/12221_SheddingLight_RPT.PDF 
25. Directive 2014/25/EU of the European Parliament and of the Council of 26 February 2014 on procurement by entities operating in the water, energy, transport and postal services sectors and repealing Directive 2004/17/EC Text with EEA relevance. URL: https://eur-lex.europa.eu/legalcontent/EN/TXT/?uri=uriserv\%3AOJ.L_.2014.094.01.0243.01.ENG

26. Quality Infrastructure Investment Database. URL: https://www.gihub.org/quality-infrastructure-database/ 27. KPMG (2017), Decommissioning Strategy: a New Imperative. URL: https://home.kpmg/uk/en/home/insights/2016/03/decommissioning-strategy-a-new-imperativefor-e-and-pfirms.html

28. MSCI SRI Indexes. URL: https://www.msci.com/msci-sri-indexes

29. EDHEC Infrastructure Database. URL: https://www.gihub.org/resources/data/edhec-infra-database/ 30. MSCI UKRAINE INDEX (USD). URL: https://www.msci.com/documents/10199/221f7a91-629a-4c2a

31. Blockchain and Tokenized Securities: The Potential for Green Finance. URL: https://www.adb.org/publications/blockchain-tokenized-securities-potential-green-finance

32. EU-Africa Infrastructure Trust Fund. URL: https://ec.europa.eu/europeaid/regions/africa/eu-africainfrastructure-trust-fund-eu-aitf_en

33. Africa-EU Energy Partnership. URL: https://ec.europa.eu/energy/en/topics/internationalcooperation/key-partner-countries-and-regions/africa

34. China's Massive Belt and Road Initiative. URL: https://www.cfr.org/backgrounder/chinas-massivebelt-and-road-initiative

35. Initiative for the Integration of Regional Infrastructure in South America. URL: https://www.internationalrivers.org/campaigns/initiative-for-the-integration-of-regional-infrastructure-insouth-america

36. Regional Integration and Economic Development In South Asia. URL: https://www.adb.org/publications/regional-integration-and-economic-development-south-asia

37. Global assets under management hit all-time high above $\$ 80$ trillion. URL: https://www.reuters.com/article/us-global-funds-aum/global-assets-under-management-hit-all-time-highabove-80-trillion-idUSKBN1CZ11B

38. 2019 Global Infrastructure Investor Survey. URL: https://cdn.gihub.org/umbraco/media/2564/globalinfrastructure-investor-survey-report-2019.pdf

39. Gosudarstvennyy dolg Ukrainy. URL: https://index.minfin.com.ua/finance/debtgov/2018/

40. EaP GREEN. URL: http://www.unece.org/env/eia/about/eap_green.html

41. The G20 Hamburg Climate and Energy Action Plan for Growth. URL: https://ec.europa.eu/energy/sites/ener/files/documents/g20-

hamburg_joint_statement_on_climate_and_energy_2017.pdf

42. Kontseptsiia pidvyshchennia efektyvnosti vprovadzhennia spilnykh z MFO proektiv. URL: http://eueaenergyagency.org/uk/home/35-ukrainian-category/2011-09-27-07-26-53/2012-05-10-13-25-14/1683-

koncepciju-pidvyshchennja-efektyvnosti-vprovadzhennja-spil-nyh-z-mfo-proektiv

43. Ukraine - Country partnership framework for the period FY17-21. URL: http://documents.worldbank.org/curated/en/847421498183265026/Ukraine-Country-partnership-frameworkfor-the-period-FY17-21. 